Volume 6 Nomor 1, Februari 2021, halaman 81 - 96.

\title{
Modul Peserta Didik Berbasis Pendekatan Matematika Realistik Kelas IV Sekolah Dasar
}

\section{Approach-Based Student Module Realistic Mathematics Class IV Primary School}

\author{
Refi Elfira Yuliani ${ }^{1}$, Heru ${ }^{2}$, Wahidati ${ }^{3}$ \\ ${ }^{1}$ Universitas Muhammadiyah Palembang, Palembang, Indonesia, rerezahra@yahoo.co.id \\ ${ }^{2}$ Universitas Muhammadiyah Palembang, Palembang, Indonesia, heroe.ump@gmail.com, \\ ${ }^{3}$ Universitas Muhammadiyah Palembang, Palembang, Indonesia, wahidatisanti@gmail.com
}

\begin{abstract}
ABSTRAK
Pembelajaran dengan menggunakan modul mempermudah pemahaman peserta didik terhadap materi pelajaran. Tujuan penelitian untuk mengembangkan modul peserta didik berbasis PMRI kelas IV Sekolah Dasar yang valid dan praktis. Pada penelitian ini, menggunakan metode pengembangan (development research). Dalam proses pengembangan peneliti memakai model 4D yang terdiri dari tahap define, design, develop, dan disseminate. Subjek yang ditentukan adalah peserta didik kelas 4B SD Islam Terpadu Salsabila Palembang. Penelitian menghasilkan produk bahan ajar berupa modul yang valid dan praktis. Kevalidan berdasarkan penilaian/review dari pakar materi, media, dan bahasa. Kepraktisan diperoleh dari hasil penilaian peserta didik terhadap modul matematika yang dilakukan pada uji lapangan terbatas melalui angket. Hasil analisis angket yang diberikan pada peserta didik pada tahap uji coba lapangan terbatas diperoleh persentase kepraktisan sebesar $88,92 \%$, sehingga dikategorikan bahwa modul matematika peserta didik berbasis pendekatan PMRI yang dikembangkan praktis. Untuk melihat Efek potensial modul diperoleh dari hasil tes yang diberikan pada peserta didik pada ujicoba operasional. Berdasarkan analisis hasil tes peserta didik pada ujicoba operasional diperoleh rata-rata nilai akhir peserta didik yaitu 80,88 yang berarti hasil belajar peserta didik tergolong kategori baik sekali. Dari hasil tersebut dapat disimpulkan bahwa modul matematika peserta didik berbasis pendekatan PMRI yang telah dikembangkan memiliki efek potensial terhadap hasil belajar peserta didik.
\end{abstract}

Kata Kunci : Model 4-D, Modul Peserta Didik, Pendidikan Matematika Realistik.

\begin{abstract}
Learning using modules makes it easier for students to understand the subject matter. The research objective was to develop student modules based on the PMRI approach for grade IV elementary schools. This study, using the development method (development research). In the development process, the researcher uses the 4D model, which consists of defining, designing, developing, and disseminating stages. The subjects determined were students in grade 4B SD Islam Terpadu Salsabila Palembang. The research resulted in teaching material products in the form of valid and practical modules. Validity is based on assessments/reviews from the material, media, and language experts. Practicality is obtained from students' assessments of the mathematics module carried out on a limited field test through a questionnaire. The questionnaire analysis results given to students in the narrow field trial stage obtained a practicality percentage of $88.92 \%$, so it is categorized that the student mathematics module based on the PMRI approach developed practically. To see the module's potential effects obtained from the test results given to students in operational trials. Based on the analysis of students' test results on operational trials, the average final score of students was 80.88, which means that the students' learning outcomes were categorized as very good. From these results, it can be concluded that the mathematics module of
\end{abstract}


students based on the PMRI approach has been developed as a potential effect on student learning outcomes.

Keywords: 4-D Model, Realistic Mathematics Education, Student modules.

How to Cite: Yuliani, R.E., Heru, H., Wahidati, W. Mathline: Jurnal Matematika dan Pendidikan Matematika. Vol. 6 No. 1, 81-96.

DOI: $\underline{\text { https://doi.org/10.31943/mathline.v6i1.196 }}$

\section{PENDAHULUAN}

Pergeseran paradigma pembelajaran abad 21 mengharuskan guru melakukan pembelajaran di kelas dengan berorientasi pada aktivitas peserta didik (Trilling \& Fadel, 2009). Hal ini diharapkan akan mampu memenuhi tuntutan terhadap keterampilan yang harus ditanamkan oleh guru pada peserta didik sehingga memenuhi karakteristik keterampilan manusia abad 21. Keterampilan tersebut seperti keterampilan berfikir kritis (critical thingking), berfikir kreatif (creativity), kolaboratif (collaboration) dan komunikasi (communication). Oleh karena itu, penggunaan model-model pembelajaran yang berorientasi pada Student Centered Learning merupakan suatu keniscayaan.

Penelitian yang dilakukan oleh Mislinawati, M., \& Nurmasyitah (2018) tentang kendala guru dalam menerapkan model-model pembelajaran diperoleh hasil observasi terhadap beberapa kegiatan yang belum maksimal dilakukan oleh guru, diantaranya guru kurang memahami langkah-langkah/sintak yang terdapat pada model pembelajaran. Sehingga, guru kurang mampu menstimulasi peserta didik untuk menemukan sendiri masalah yang ada pada materi pembelajaran.

Berdasarkan penelitian tersebut, upaya yang dilakukan untuk menunjang keberhasilan dari solusi yang diberikan yaitu dengan penggunaan bahan ajar yang dilengkapi oleh sintak model pembelajaran. Bahan yang dilengkapi dengan sintak model pembelajaran akan mempermudah seorang guru dalam menerapkan model pembelajaran. Menurut Anggoro (2015) pembelajaran dengan menggunakan modul mempermudah pemahaman peserta didik terhadap materi pelajaran dan mencapai suatu tujuan pembelajaran yang diinginkan, karena modul memberikan ruang kepada peserta didik untuk belajar mandiri serta pemecahan masalah dengan cara mengeluarkan ide-ide baru dengan arahan guru.

Salah satu pendekatan pembelajaran matematika yaitu PMRI (Pendidikan Matematika Realistik Indonesia). PMRI adalah suatu pendekatan yang menyajikan pembelajaran realistik (Heuvel-panhuizen et al., 2014; Hirza et al., 2014; Zulkardi et al., 2020) atau sesuatu yang dapat dibayangkan secara nyata dan dipahami untuk memecahkan 
masalah (Ismunandar et al., 2020). Hal ini senada dengan hasil penelitian Rahmawati (2013) yang menyatakan bahwa pembelajaran matematika menggunakan pendekatan PMRI sangat potensial meningkatkan kemampuan komunikasi matematis siswa. Pada penelitian ini PMRI merupakan pendekatan pembelajaran matematika yang dapat mengintegrasikan kemampuan berfikir kritis (critical thingking), kemampuan berfikir kreatif (creativity), dan kemampuan komunikasi (communication) peserta didik. Meirisa dkk (2018) melalui hasil penelitiannya menyatakan bahwa penggunaan PMRI memberikan pengaruh terhadap keterampilan berpikir kritis siswa di kelas V SD Negeri 44 Kalumbuk Kota Padang. Dwipayana dkk (2018) pendekatan PMRI berbasis open ended berpengaruh terhadap kemampuan berpikir kreatif Matematika siswa kelas V SD di Gugus VII Kecamatan Sukasada tahun pelajaran 2017/2018.

Berdasarkan kajian diatas, peneliti mengembangkan modul peserta didik berbasis pendekatan Pendidikan Matematika Realistik Indonesia yang valid dan praktis serta dapat memberikan efek potensial terhadap hasil belajar peserta didik. Diharapkan melalui modul ini peserta didik dapat memudahkan guru untuk menerapkan pendekatan Pendidikan Matematika Relistik Indonesia di kelas.

\section{METODE PENELITIAN}

Jenis penelitian yang akan digunakan adalah penelitian pengembangan (Development Research) menggunakan model penelitian pengembangan 4-D (Define, Design, Develop and Disseminate) yang dikembangkan oleh Thiagarajan, S., Semmel, D., \& Semmel (1974).

Instrumen yang digunakan pada penelitian ini berupa angket dan tes. Angket digunakan untuk memperoleh data berupa tanggapan terhadap modul matematika peserta didik berbasis PMRI yang dikembangkan. Angket diberikan kepada para ahli pada saat dilakukan validasi dan kepada peserta didik pada saat uji coba lapangan terbatas. Tes dalam penelitian ini dilakukan pada ujicoba lapangan. Tes digunakan untuk memperoleh data tentang hasil belajar peserta didik dan melihat efek potensial modul matematika peserta didik berbasis PMRI terhadap hasil belajar peserta didik tersbut setelah mendapatkan pembelajaran dengan menggunakan modul matematika peserta didik berbasis pendekatan PMRI. Hasil belajar tersebut diperoleh dengan memeriksa lembar jawaban latihan dan lembar jawaban tes akhir peserta didik

Teknik analisis angket menggunakan teknik analisis data kombinasi kuantitatif dan kualitatif. Data kualitatif diperoleh dari angket penilaian berupa saran dan komentar dari 
pada ahli materi, ahli media/tampilan modul, dan ahli bahasa pada saat validasi. Sedangkan analisis data kuantitatif diperoleh dari angket penilaian respon peserta didik pada saat uji lapangan terbatas dengan menggunakan skala likert, selanjutnya diolah dengan cara dibuat persentase dengan rumus sebagai berikut (Sugiyono, 2016):

$$
\begin{aligned}
& \mathrm{X}=\frac{\text { jumlah penilaian seluruh peserta didik }}{\text { penilaian sempurna }} \times 100 \% \\
& \mathrm{X}=\text { Persentase skor }
\end{aligned}
$$

Hasil yang diperoleh dengan perhitungan di atas berguna untuk mengembangkan kesimpulan yaitu:

Tabel 1. Kriteria Kepraktisan

\begin{tabular}{lc}
\hline Persentase & Kriteria Kepraktisan \\
\hline $0 \%-25 \%$ & Tidak ada aspek kepraktisan \\
$25 \%-50 \%$ & Cukup rendah memenuhi aspek kepraktisan \\
$50 \%-75 \%$ & Cukup tinggi memenuhi aspek kepraktisan \\
$75 \%-100 \%$ & Memenuhi aspek kepraktisan \\
\hline
\end{tabular}

Modul yang dikembangkan dapat dikatakan "praktis" jika persentase kepraktisan mencapai $>75 \%$. Modul yang dikembangkan dikatakan "tidak praktis" jika persentase kepraktisan $\leq 75 \%$.

Tabel 2. Penilaian total instrumen peserta didik

\begin{tabular}{ll}
\hline Persentase & Kategori \\
\hline$>75 \%$ & Praktis \\
$\leq 75 \%$ & Tidak Praktis \\
\hline
\end{tabular}

Analisis hasil tes dilakukan untuk melihat efek potensial dari modul matematika peserta didik berbasis pendekatan PMRI yang dikembangkan. Untuk melihat pencapaian kemampuan belajar dalam proses pembelajaran dengan memeriksa lembar jawaban tes peserta didik kemudian dianalisis dan dikelompokkan dalam kategori sebagai berikut:

Tabel 3 Kategori Penilaian Hasil belajar Peserta Didik

\begin{tabular}{cc}
\hline Nilai peserta didik & Kategori \\
\hline $86-100$ & Baik Sekali \\
$75-85$ & Baik \\
$56-74$ & Cukup \\
$40-55$ & Kurang \\
$0-39$ & Sangat Kurang \\
\hline
\end{tabular}

Modifikasi Arikunto (2012)(Arikunto, 2012)(Arikunto, 2012)(Arikunto, 2012) 


\section{HASIL DAN PEMBAHASAN}

\section{Tahap Pendefinisian (Define)}

Pada tahap ini dilakukan penetapan dan pendefinisian syarat-syarat pengembangan. Hasil dari tahap pendefinisian ini berupa rencana pelaksanaan pembelajaran, draf rancangan modul dengan menggunakan Pendekatan Realistik Indonesia.

\section{Tahap Perancangan (Design)}

Tahap ini merupakan tahap desain awal. Pada tahap ini dirancang modul matematika peserta didik berbasis pendekatan PMRI yang kemudian akan divalidasi oleh ahli. Bagian-bagian modul terdiri dari: 1) bagian pendahuluan terdapat kata pengantar, daftar isi, Kompetensi Dasar, indikator pembelajaran, tujuan pembelajaran, deskripsi modul, petunjuk penggunaan modul dan peta konsep; 2) bagian isi, terdapat aktivitas-aktivitas yang dilakukan peserta didik, uraian materi, dan latihan yang akan dikerjakan oleh peserta didik. 3) bagian penutup terdapat rangkuman dan daftar pustaka.
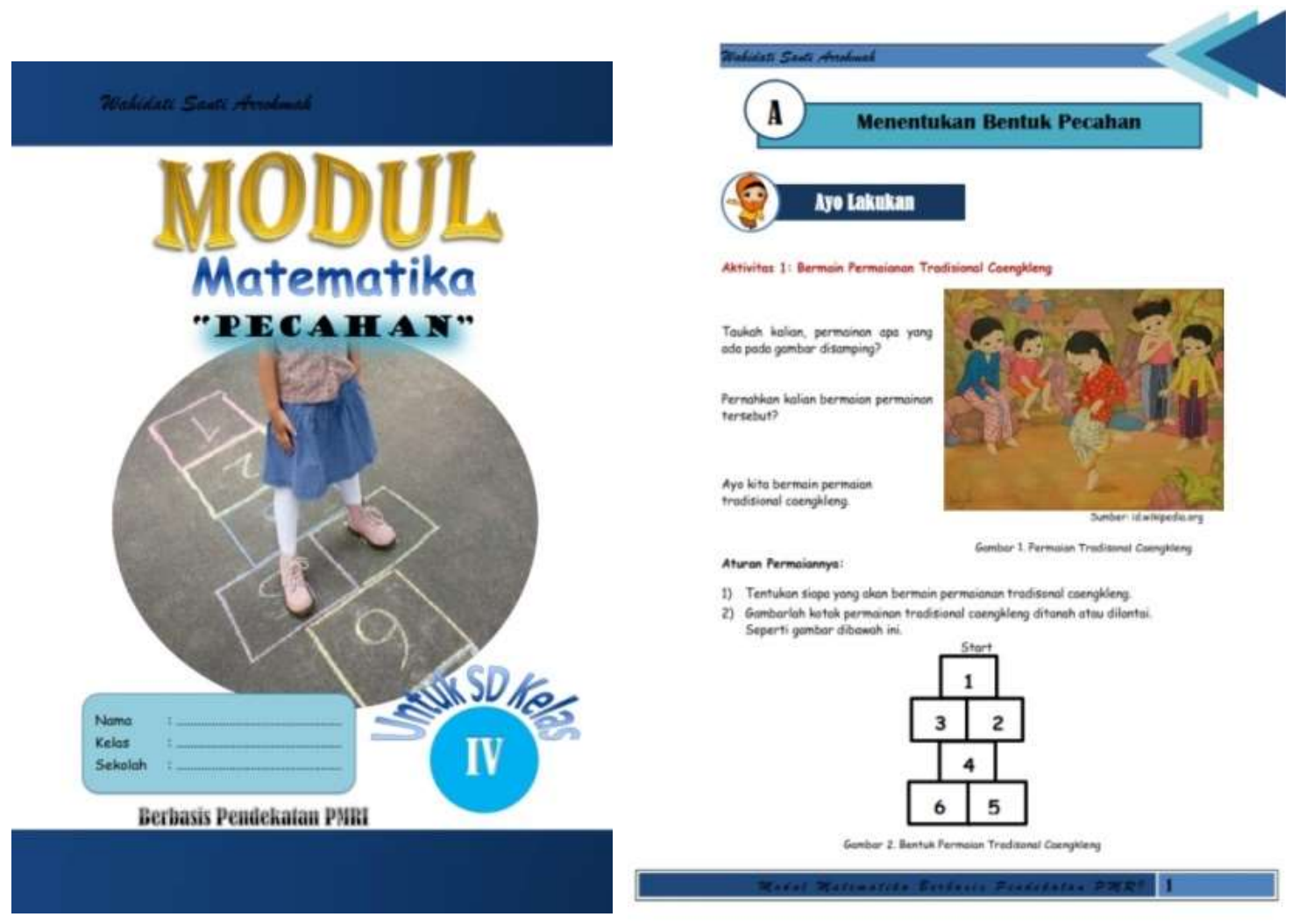

\section{Gambar 1. Tampilan Modul Peserta Didik}

\section{Tahap Pengembagan (Develop)}

Tahap pengembangan terdiri atas penilaian validasi ahli (materi, media dan bahasa) dan uji pengembangan produk. Prototype yang telah divalidasi dan diperbaiki akan diuji cobakan secara 
terbatas pada subjek non sampel dan diuji cobakan secara operasional dengan melibatkan peserta didik kelas IV.B SD IT Salsabila Palembang.

Validasi materi dilakukan untuk menilai kesesuain prototype I terhadap kompetensi dasar, indikator dan pendekatan PMRI. Adapun komentar dan saran yang diberikan validator serta revisi yang telah dilakukan peneliti disajikan pada Tabel 4

Tabel 4. Hasil revisi modul matematika peserta didik berbasis pendekatan PMRI berdasarkan komentar dan saran dari validator materi.

\begin{tabular}{|c|c|}
\hline & SEBELUM REVISI \\
\hline 3) & Wasing-nusing pencin menedidan lenperyon atau betu cape: \\
\hline 4) & 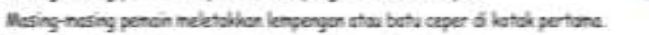 \\
\hline 5) & Senva pengin melakjo isit and meventhor unto bernoin. \\
\hline 6) & 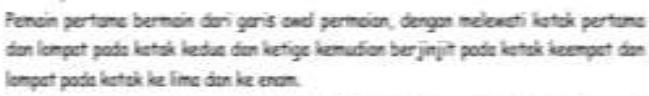 \\
\hline 7$)$ & 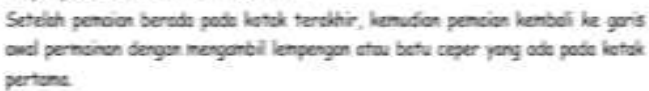 \\
\hline 8) & 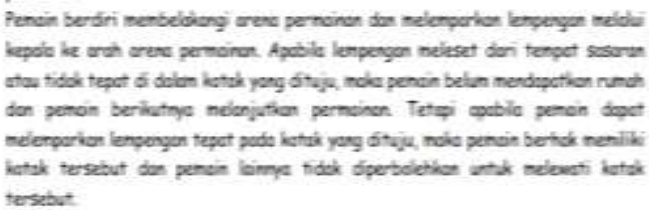 \\
\hline 9) & 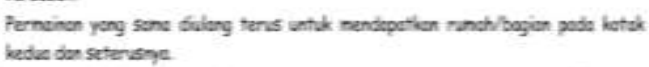 \\
\hline & 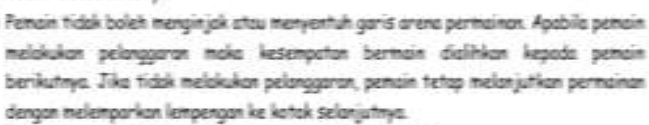 \\
\hline & 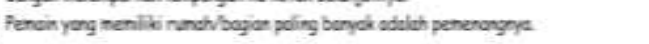 \\
\hline
\end{tabular}

Komentar dan saran:

Sederhanakan kalimat pada langkahlangkah permainan tradisional caengkleng.

1. Langkah no 3 :'Masing-masing pemain menyediakan lempengan atau batu ceper".

2. Langkah no 4 :'Masing-masing pemain meletakan lempengan atau batu ceper di kotak pertama".

3. Langkah no 5: "Semua pemain melakukan usit untuk menentukan urutan bermain".

4. Langkah no 6: "Pemain pertama bermain dari garis awal permainan, dengan melewati kotak pertama dan lompat pada kotak kedua dan ketiga kemudian berjinjit pada kotak keempat dan lompat pada kotak kelima dan keenam.

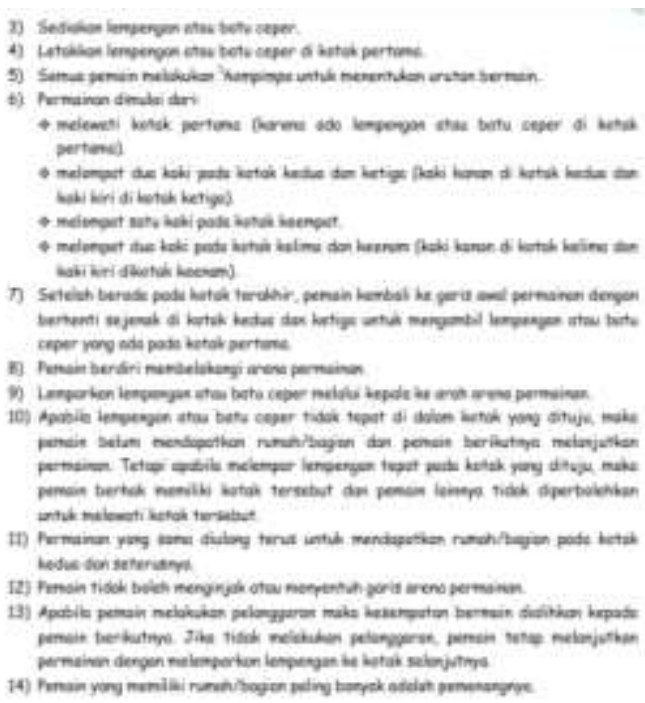

Perbaikan:

Mengganti kalimat yang susah dipahami khususnya untuk anak sekolah dasar.

1. Langkah no 3 menjadi:

"Sediakan lempengan atau batu ceper".

2. Langkah no 4 menjadi:

"Letakkan lempengan atau batu ceper di kotak pertama".

3. Langkah no 5 menjadi:

"Semua pemain melakukan hompimpa untuk menentukan urutan bermain".

4. Langkah no 6 menjadi:

"Permainan dimulai dari:

- melewati kotak pertama (karena ada lempengan atau batu ceper di kotak pertama).

- melompat dua kaki pada kotak kedua dan ketiga (kaki kanan di kotak kedua dan kaki kiri di kotak ketiga).

- melompat satu kaki pada kotak keempat.

- melompat dua kaki pada kotak 


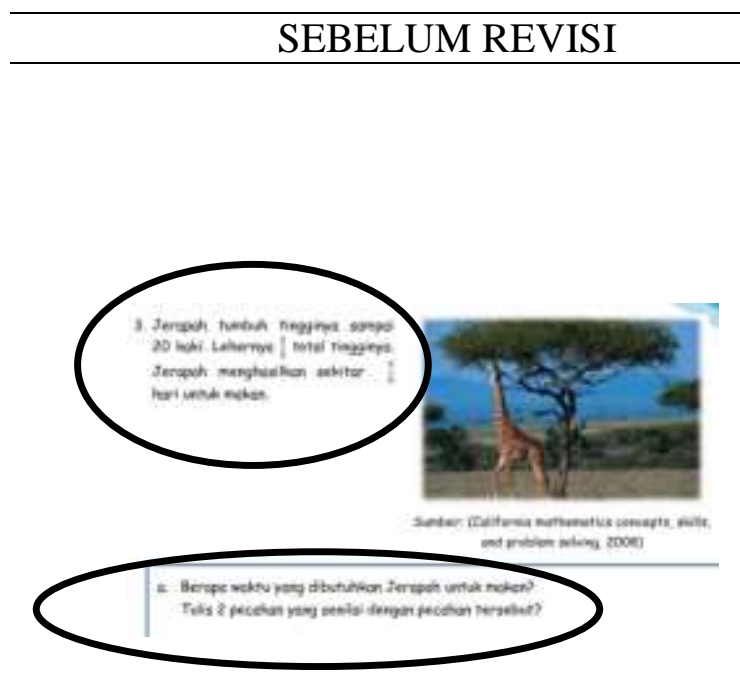

SETELAH REVISI

kelima dan keenam (kaki kanan di kotak kelima dan kaki kiri dikotak keenam)."

Komentar dan saran:

Perbaiki redaksi soal no 3 agar peserta didik dapat menjawab sesuai dengan yang diharapkan.

"Jerapah tumbuh tingginya 20 kaki. Lehernya $\frac{2}{5}$ total tingginya. Jerapah menghasilkan sekitar $\frac{5}{6}$ hari untuk makan.

a. Berapa waktu yang dibutuhkan Jerapah untuk makan? Tulislah 2 pecahan yang senilai dengan pecahan tersebut!”.

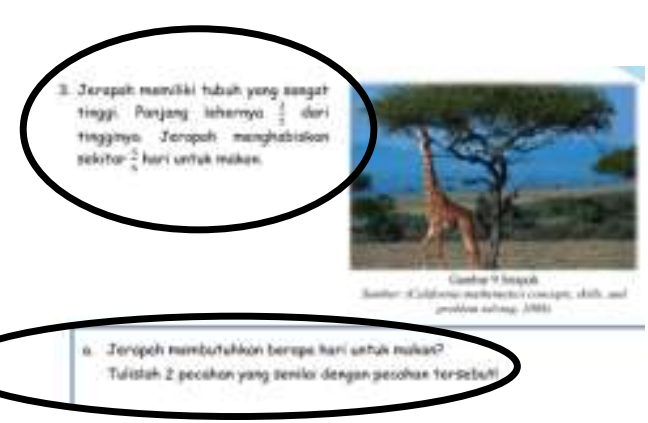

Perbaikan:

Mengubah redaksi soal no 3 agar peserta didik dapat menjawab sesuai dengan yang diharapkan menjadi:

"Jerapah memiliki tubuh yang sangat tinggi. Panjang lehernya $\frac{2}{5}$ dari tingginya. Jerapah menghabiskan sekitar $\frac{5}{6}$ hari untuk makan.

a. Jerapah membutuhkan berapa hari untuk makan? Tulislah 2 pecahan yang senilai dengan pecahan tersebut!".

Validasi media dilakukan untuk menilai kesesuaian tampilan pada modul yang dikembangkan. Adapun komentar dan saran yang diberikan validator serta revisi yang telah dilakukan peneliti disajikan pada Tabel 5.

Tabel 5. Hasil revisi modul matematika peserta didik berbasis pendekatan PMRI berdasarkan komentar dan saran dari validator media/tampilan.



\begin{tabular}{|c|c|}
\hline SEBELUM REVISI & SETELAH REVISI \\
\hline Komentar dan saran: & Perbaikan: \\
\hline $\begin{array}{l}\text { 1. Perbaiki judul pada sampul, kata } \\
\text { "Pecahan" lebih dominan daripada kata }\end{array}$ & $\begin{array}{l}\text { 1. Memperbaiki ukuran penulisan judul pada } \\
\text { sampul modul. }\end{array}$ \\
\hline $\begin{array}{l}\text { "Modul Matematika". } \\
\text { 2. Perbaiki warna tulisan nama pengarang } \\
\text { pada sampul agar lebih kontras. }\end{array}$ & $\begin{array}{l}\text { 2. Mengubah warna tulisan nama pengarang } \\
\text { dari hitam menjadi putih agar menjadi } \\
\text { lebih kontras. }\end{array}$ \\
\hline
\end{tabular}
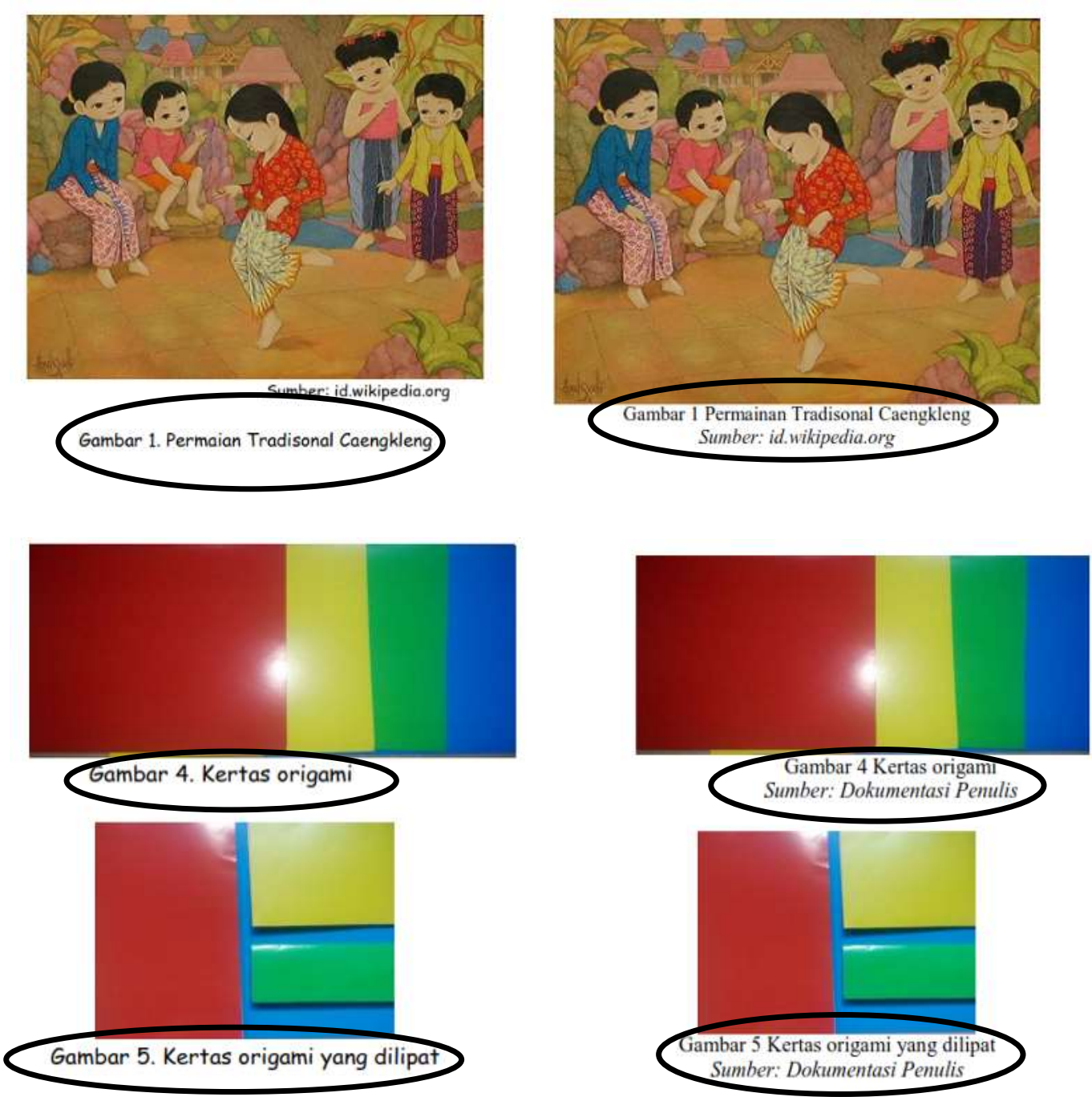

Komentar dan saran:

Perbaikan:

Perbaiki keterangan pada setiap gambar seharusnya keterangan gambar di tempatkan berdekatan dengan gambar dan Memperbaiki jenis huruf dan jarak berbeda dari huruf teks.

keterangan pada setiap gambar.

Validasi bahasa dilakukan untuk menilai kesesuaian prototype I terhadap bahasa yang digunakan pada modul yang dikembangkan. Adapun komentar dan saran yang diberikan validator serta revisi yang telah dilakukan peneliti disajikan pada Tabel 6. 
Tabel 6. Hasil revisi modul matematika peserta didik berbasis pendekatan PMRI berdasarkan komentar dan saran dari validator bahasa.

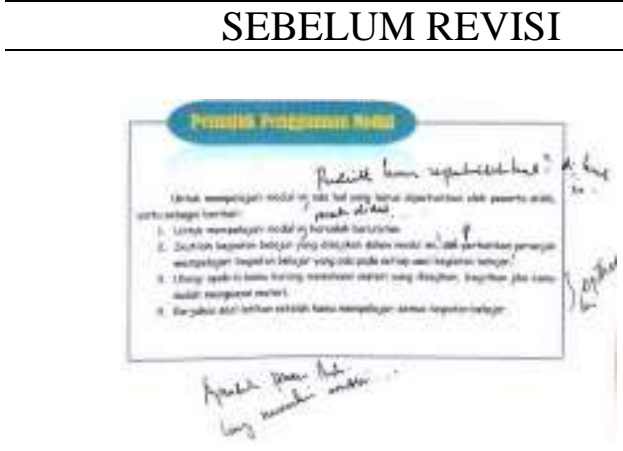

Komentar dan saran:

Perbaiki tata bahasa dan ejaan yang digunakan pada bagian petunjuk penggunaan modul:

1. Untuk mempelajari modul ini, ada hal yang harus diperhatikan oleh peserta didik, yaitu sebagai berikut:

2. Untuk mempelajari modul ini haruslah berurutan.

3. Ikutilah kegiatan belajar yang disajikan dalam modul ini, dan perhatikan petunjuk mempelajari kegiatan belajar yang ada pada setiap awal kegiatan belajar.

4. Ulangi apabila kamu kurang memahami materi yang disajikan, lanjutkan jika kamu sudah menguasai materi.

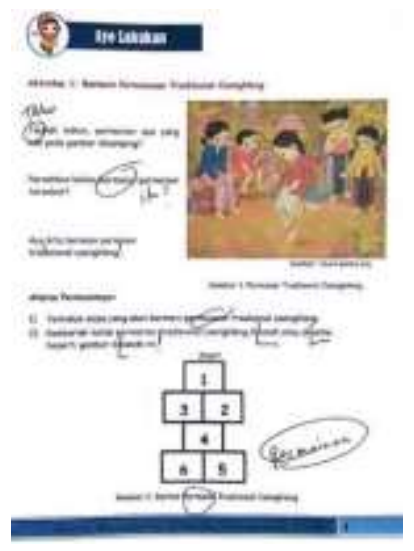

Komentar dan saran:

Perbaiki struktur kalimat, tata bahasa, ejaan dan tanda baca pada halaman 1 ,

1. Taukah kalian

2. Pernahkan kalian bermain permainan tersebut?

3. Tentukan siapa yang bermain

SETELAH REVISI

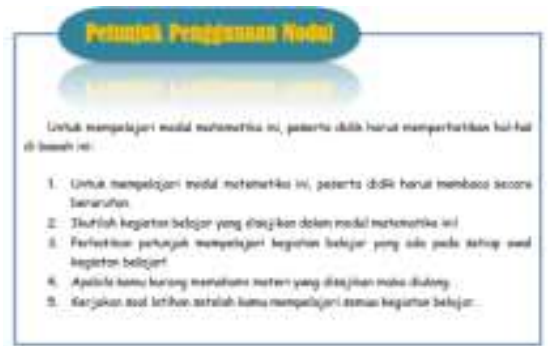

Perbaikan:

Memperbaiki tata bahasa dan ejaan yang digunakan sesuai saran:

1. Untuk mempelajari modul matematika ini, peserta didik harus memperhatikan hal-hal di bawah ini:

2. Untuk mempelajari modul matematika ini, peserta didik harus membaca secara berurutan.

3. Ikutilah kegiatan belajar yang disajikan dalam modul matematika ini!

Perhatikan petunjuk mempelajari kegiatan belajar yang ada pada setiap awal kegiatan belajar!

4. Apabila kamu kurang memahami materi yang disajikan maka diulang.

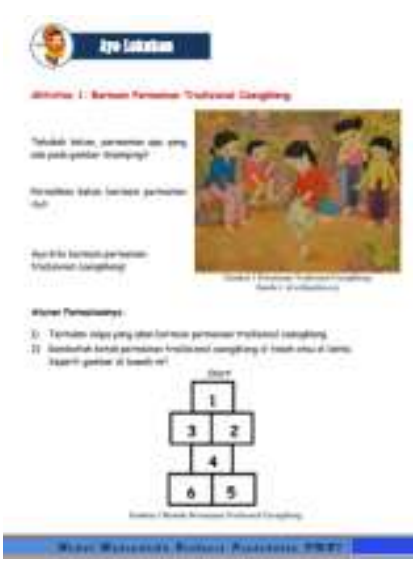

Perbaikan:

Memperbaiki struktur kalimat, tata bahasa, ejaan dan tanda baca sesuai saran:

1. Tahukah kalian

2. Pernahkan kalian bermain permainan itu?

3. Ayo, kita bermain permainan tradisional 
SEBELUM REVISI

permaianan tradisional caengkleng.

4. Ayo kita bermain permainan tradisional caengkleng.

5. Gambarlah kotak permainan tradisional caengkleng ditanah atau dilantai. Seperti gambar dibawah ini.
SETELAH REVISI

caengkleng!

4. Tentukan siapa yang bermain permainan tradisional caengkleng.

5. Gambarlah kotak permainan tradisional caengkleng di tanah atau di lantai. Seperti gambar di bawah ini!

Setelah dilakukan revisi terhadap saran perbaikan oleh pakar, selanjutnya dilakukan uji coba lapangan terbatas terhadap 8 peserta didik kelas non sampel SD IT Salsabila Palembang.

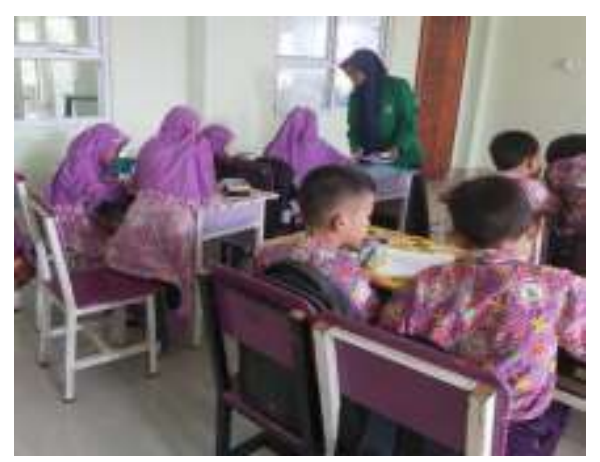

\section{Gambar 2. Pembelajaran Pada Saat Uji Coba Lapangan Terbatas}

Pada gambar 2 peneliti melakukan pangamatan terhadap aktivitas peserta didik. Berdasarkan hasil pengamatan yang dilakukan diperoleh kesimpulan bahwa peserta didik tidak mengalami kesulitan dalam menggunakan modul matematika peserta didik berbasis PMRI, peserta didik dapat mengikuti langkah-langkah pembelajaran dalam menggunakan modul matematika peserta didik berbasis PMRI, dan peserta didik mampu menyelesaikan soal latihan yang ada pada modul matematika peserta didik berbasis PMRI, hanya saja terdapat peserta didik yang belum memahami aturan permaian tradisional caengkleng yang ada pada modul sehingga membutuhkan waktu yang lama untuk mencermatinya. Selain itu, ada seorang peserta didik yang mengalami kesulitan pada saat mengerjakan aktivitas 2 halaman 3, dikarenakan kurangnya kecermatan memahami petunjuk di dalam pengerjaannya. Namun, secara keseluruhan peserta didik tidak mengalami kesulitan.

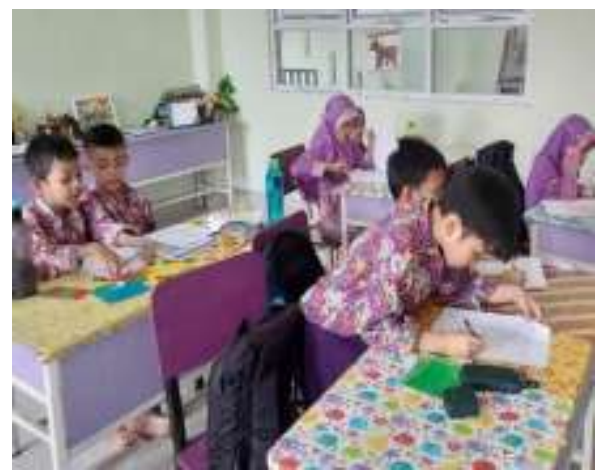

Gambar 3. Peserta Didik Menjawab Pertanyaan pada Angket Respon Peserta Didik 
Setelah melakukan pembelajaran, peserta didik diminta untuk memberikan penilaian terhadap modul matematika peserta didik berbasis PMRI seperti yang ditunjukkan pada gambar 3. Peserta didik melakukan penilaian modul dengan mengisi lembar angket respon peserta didik yang telah disediakan oleh peneliti. Berikut hasil analisis penilaian pada angket respon peserta didik.

Tabel 7. Hasil penilaian angket respon peserta didik pada uji coba lapangan terbatas.

\begin{tabular}{|c|c|c|c|c|c|c|c|c|c|c|c|}
\hline \multirow{2}{*}{ No } & \multirow{2}{*}{ Aspek yang Dinilai } & \multicolumn{8}{|c|}{ Kode Peserta Small Group } & \multirow{2}{*}{$\begin{array}{c}\text { Jumlah } \\
\text { Penilaian }\end{array}$} & \multirow{2}{*}{ Persentase } \\
\hline & & 1 & 2 & 3 & 4 & 5 & 6 & 7 & 8 & & \\
\hline 1. & $\begin{array}{lr}\text { Saya tertarik dengan } \\
\text { tampilan } \\
\text { matematika ini }\end{array}$ & 4 & 4 & 3 & 3 & 3 & 3 & 4 & 4 & 28 & $50 \%$ \\
\hline 2. & $\begin{array}{l}\text { Saya lebih } \text { bersemangat } \\
\text { belajar } \\
\text { dengan mematika } \\
\text { modul matematika ini. }\end{array}$ & 4 & 4 & 4 & 3 & 4 & 4 & 4 & 4 & 31 & $87,5 \%$ \\
\hline 3. & $\begin{array}{l}\text { Saya tidak merasa bosan } \\
\text { saat belajar menggunakan } \\
\text { modul matematika ini. }\end{array}$ & 4 & 4 & 2 & 3 & 3 & 2 & 4 & 4 & 26 & $50 \%$ \\
\hline 4. & $\begin{array}{l}\text { Saya merasa terdukung } \\
\text { belajar matematika } \\
\text { menggunakan modul } \\
\text { matematika ini, khususnya } \\
\text { materi pecahan. }\end{array}$ & 4 & 4 & 2 & 4 & 2 & 3 & 4 & 4 & 27 & $62,5 \%$ \\
\hline 5. & $\begin{array}{l}\text { Saya termotivasi untuk } \\
\text { mempelajari materi } \\
\text { dengan adanya ilustrasi } \\
\text { pada modul matematika } \\
\text { ini. }\end{array}$ & 3 & 4 & 2 & 4 & 2 & 4 & 4 & 4 & 27 & $62,5 \%$ \\
\hline 6. & $\begin{array}{l}\text { Saya mudah memahami } \\
\text { materi dalam modul } \\
\text { matematika ini karena } \\
\text { berkaitan dengan } \\
\text { kehidupan sehari-hari. }\end{array}$ & 4 & 4 & 4 & 3 & 4 & 3 & 4 & 4 & 30 & $75 \%$ \\
\hline 7. & $\begin{array}{l}\text { Saya menemukan konsep } \\
\text { sendiri dibeberapa bagian } \\
\text { dalam modul matematika } \\
\text { ini. }\end{array}$ & 4 & 4 & 2 & 3 & 3 & 4 & 4 & 4 & 28 & $62,5 \%$ \\
\hline 8. & $\begin{array}{l}\text { Saya terdorong untuk } \\
\text { berdiskusi dengan teman } \\
\text { yang lain tentang materi } \\
\text { dalam modul matematika } \\
\text { ini }\end{array}$ & 4 & 4 & 3 & 3 & 3 & 2 & 4 & 4 & 27 & $50 \%$ \\
\hline 9. & $\begin{array}{l}\text { Saya dapat menguji } \\
\text { seberapa jauh pemahaman } \\
\text { tentang materi pecahan }\end{array}$ & 4 & 4 & 3 & 3 & 2 & 4 & 4 & 4 & 28 & $62,5 \%$ \\
\hline
\end{tabular}




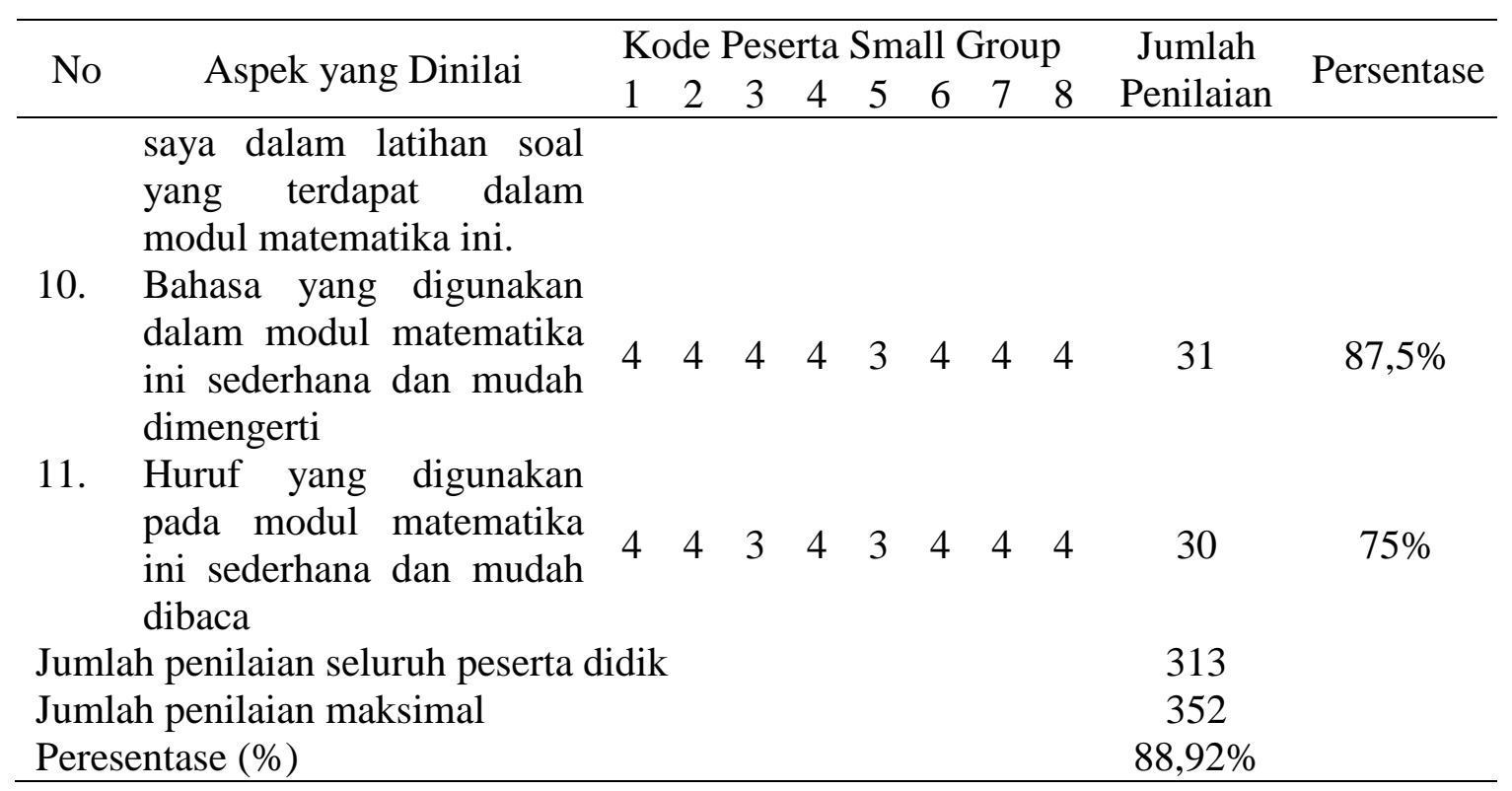

Menghitung persentase skor:

$$
\begin{aligned}
& X=\frac{\text { jumlah penilaian seluruh peserta didik }}{\text { penilaian sempurna }} \times 100 \% \\
& X=\frac{313}{352} \times 100 \% \\
& X=88,92 \%
\end{aligned}
$$

Berdasarkan data hasil penilaian peserta didik pada tahap uji coba lapangan terbatas, modul matematika peserta didik berbasis pendekatan PMRI mendapatkan jumlah skor 313 dari jumlah total maksimal penilaian 352. Jumlah skor tersebut dikonversi dalam bentuk persen sebesar $88,92 \%$ dan dapat dikategorikan bahwa modul matematika peserta didik berbasis pendekatan PMRI yang dikembangkan dapat dikategorikan "Praktis".

Langkah selanjutnya adalah melakukan uji coba lapangan operasional pada subjek sampel penelitian, yaitu kelas IV.B SD IT Salsabila Palembang yang berjumlah 17 peserta didik yang terdiri dari 7 peserta didik perempuan dan 10 peserta didik laki-laki. Uji coba lapangan operasional dilakukan untuk melihat efek potensial dari modul matematika yang dikembangkan.

Pada tahap uji coba lapangan operasional dilakukan tiga kali pertemuan yaitu pertemuan pertama peserta didik melakukan pembelajaran dengan menggunakan modul matematika peserta didik berbasis pendekatan PMRI yang membahas materi menentukan bentuk pecahan. Sebelum melakukan pembelajaran, peneliti menjelaskan terebih dahulu cara menggunaan modul matematika peserta didik berbasis pendekatan PMRI sehingga kegiatan pembelajaran dapat terlaksana dengan baik. Pada awal pembelajaran, peneliti menjelaskan tujuan dari pembelajaran yang akan dicapai. Pada kegiatan inti, peneliti 
mengamati serta memandu peserta didik dalam menjalankan aktivitas yang terdapat pada modul. Gambar dibawah ini merupakan salah satu aktivitas penggunaan konteks dalam pembelajaran menggunakan Pendekatan Matematika Realistik Indonesia. Konteks yang digunakan adalah permaianan tradisional caengkleng.

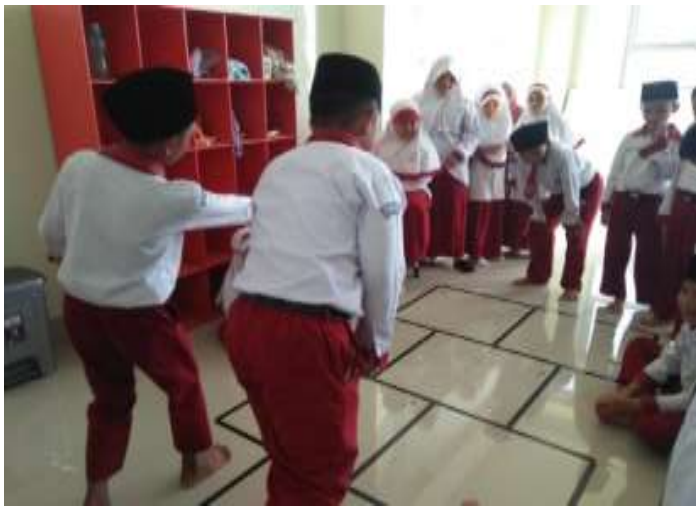

\section{Gambar 5. Kegiatan Bermain Permainan Tradisional Caengkleng}

Pertemuan kedua, peserta didik melakukan pembelajaran dengan menggunakan modul matematika siswa berbasis pendekatan PMRI yang membahas materi pecahan senilai dengan menggunakan kertas origami seperti gambar dibawah ini.

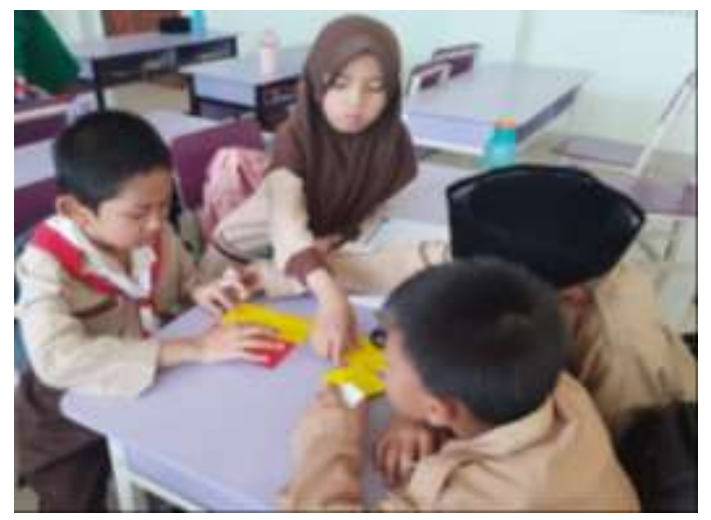

\section{Gambar 6. Menempatkan Potongan Kertas Origami di atas Kertas Origami yang Utuh}

Pada gambar 6, peserta didik diminta mengikuti setiap aktivitas dan menyelesaikan permasalahan realistik yang ada pada modul sesuai dengan pendekatan yang dipakai di dalam modul.

Pertemuan ketiga, peserta didik melakukan pembelajaran dengan menggunakan modul matematika siswa berbasis pendekatan PMRI yang membahas materi membandingkan dan mengurutkan pecahan. Kemudian, peserta didik diminta mengikuti 
setiap aktivitas dan menyelesaikan permasalahan realistik yang ada pada modul sesuai dengan pendekatan yang dipakai di dalam modul.

Pada akhir pembelajaran matematika dengan menggunakan modul matematika peserta didik berbasis pendekatan PMRI, peserta didik diminta untuk menjawab soal tes akhir yang bertujuan untuk melihat efek potensial dari modul yang dikembangkan. Data yang telah diperoleh dianalisis untuk melihat rata-rata hasil belajar yang diperoleh peserta didik. Berikut hasil penghitungan terhadap hasil belajar peserta didik.

Tabel 8. Hasil Nilai Tes Akhir Peserta Didik

\begin{tabular}{llcc}
\hline No & Nama Peserta Didik & Nilai & Kategori \\
\hline 1 & AD & 85 & Baik Sekali \\
2 & MDH & 80 & Baik Sekali \\
3 & AR & 75 & Baik \\
4 & NRI & 80 & Baik Sekali \\
5 & AS & 100 & Baik Sekali \\
6 & IA & 90 & Baik Sekali \\
7 & RAV & 80 & Baik Sekali \\
8 & MLS & 100 & Baik Sekali \\
9 & DZA & 95 & Baik Sekali \\
10 & GAD & 100 & Baik Sekali \\
11 & MFA & 65 & Cukup \\
12 & MIB & 30 & Sangat Kurang \\
13 & HS & 100 & Baik Sekali \\
14 & IKW & 55 & Kurang \\
15 & LZ & 70 & Baik \\
16 & NK & 100 & Baik Sekali \\
17 & RAP & 70 & Baik \\
Jumlah & 1375 & \\
Jumlah Maksimal & 1700 & \\
Rata-rata & 80,88 & Baik Sekali \\
\hline
\end{tabular}

Tabel 9. Distribusi Frekuensi Hasil Tes Akhir

\begin{tabular}{cccc}
\hline $\begin{array}{c}\text { Nilai Peserta } \\
\text { Didik }\end{array}$ & Frekuensi & Persentase & Kategori \\
\hline $80-100$ & 11 & $64,70 \%$ & Baik Sekali \\
$66-79$ & 3 & $17,65 \%$ & Baik \\
$56-65$ & 1 & $5,88 \%$ & Cukup \\
$40-55$ & 1 & $5,88 \%$ & Kurang \\
$0-39$ & 1 & $5,88 \%$ & Sangat Kurang \\
Jumlah & 17 & $100 \%$ & \\
\hline
\end{tabular}


Berdasarkan Tabel 9 diperoleh rata-rata nilai akhir peserta didik yaitu 80,88 yang berarti hasil belajar peserta didik tergolong kategori baik sekali, dimana terdapat 11 peserta didik $(64,70 \%)$ kategori sangat baik, 3 peserta didik (17,65\%) kategori baik, 1 peserta didik (5,88\%) kategori cukup, 1 peserta didik (5,88\%) kategori kurang, dan 1 peserta didik $(5,88 \%)$ kategori sangat kurang. Berdasarkan analisis terhadap hasil belajar peserta didik dapat disimpulkan bahwa modul matematika yang dikembangkan memiliki efek potensial terhadap hasil belajar peserta didik.

\section{Tahap Desimination (Desiminasi)}

Tahap terakhir merupakan tahap desiminasi. Desiminasi modul matematika peserta didik berbasis pendekatan PMRI dilakukan di hadapan para guru SDIT Salsabila. Pada tahap ini, peneliti memaparkan modul matematika peserta didik berbasis pendekatan PMRI yang dikembangkan dan memberikan penjelasan cara penggunaan modul tersebut kepada kepala sekolah dan guru-guru di SD IT Salsabila Palembang.

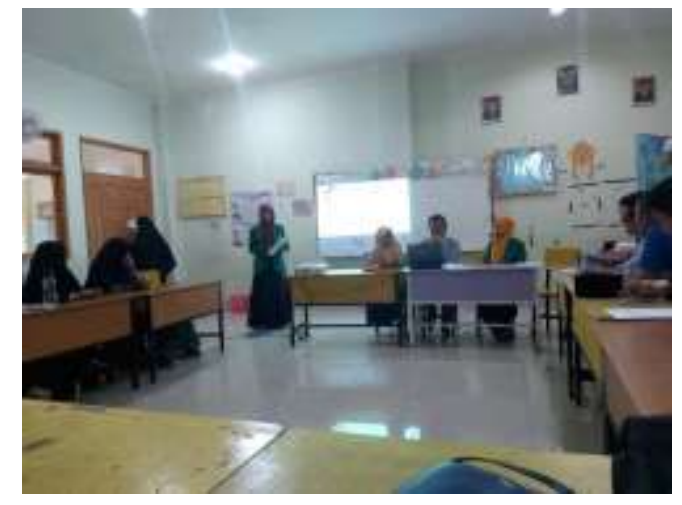

\section{Gambar 7. Kegiatan Pemaparan Modul Pada Saat Desiminasi}

Pada gambar 7, peneliti menjelaskan setiap aktivitas yang terdapat pada modul tersebut, kemudian peserta dari desiminasi modul ini diberikan kesempatan untuk mendiskusikan terkaitkan tentang modul matematika peserta didik berbasis pendekatan PMRI yang telah dipaparkan oleh peneliti.

\section{KESIMPULAN}

Berdasarkan hasil penelitian dan pembahasan yang telah diuraikan maka dapat disimpulkan bahwa modul matematika peserta didik berbasis Pendekatan PMRI kelas IV Sekolah Dasar pada materi bentuk pecahan yang dikembangkan telah dikategorikan valid dan praktis serta memiliki efek potensial terhadap hasil belajar peserta didik. 
Peneliti berharap dilakukan pengembangan modul matematika peserta didik pada materi lainnya dengan menggunakan pendekatan PMRI, sehingga para guru memiliki referensi yang memadai dalam menunjang mereka menerapkan pembelajaran matematika menggunakan pendekatan PMRI.

\section{DAFTAR PUSTAKA}

Anggoro, B. S. (2015). Pengembangan Modul Matematika Dengan Strategi Problem Solvin Guntuk Mengukur Tingkat Kemampuan Berpikir Kreatif Matematis Siswa. Al-Jabar, 6(2), 121-129.

Arikunto, S. (2012). S. Arikunto, Dasar-dasar evaluasi pendidikan. Jakarta: Bumi Aksara. Ismail, A. D. (2019). Pengembangan Modul Berbasis Matematika Realistik Bercirikan Budaya Indonesia. Kalamatika, 4(2), 177-192.

Heuvel-panhuizen, M. Van Den, Drijvers, P., Education, M., Sciences, B., \& Goffree, F. (2014). Encyclopedia of Mathematics Education. Encyclopedia of Mathematics Education. https://doi.org/10.1007/978-94-007-4978-8

Hirza, B., Kusumah, Y. S., Darhim, \& Zulkardi. (2014). Improving intuition skills with realistic mathematics education. Journal on Mathematics Education, 5(1), 27-34. https://doi.org/10.22342/jme.5.1.1446.27-34

Ismunandar, D., Gunadi, F., Taufan, M., Mulyana, D., \& Runisah. (2020). Creative thinking skill of students through realistic mathematics education approach. Journal of Physics: Conference Series, 1657(1), 012054. https://doi.org/10.1088/17426596/1657/1/012054

M. Thiagarajan, S. S. (1974). Instructional development for training teacher of expectional children: A sourcebook. Indiana: Indiana University.

Meirisa, A., Rifandi, R., \& Masniladev. (2018). Pengaruh Pendekatan Pendidikan Matematika Realistik Indonesia (PMRI) Terhadap Keterampilan Berpikir Kritis Siswa SD. Jurnal Gantang, 3(2), 127-134.

Mislinawati, \& Nurmasyitah. (2018). Kendala guru dalam menerapkan model-model pembelajaran berdasarkan kurikulum 2013 pada sd negeri 62 Banda Aceh. Pesona Dasar, 6(2), 22-32.

Rahmawati, F. (2013). Pengaruh Pendekatan Pendidikan Realistik Matematika dalamMeningkatkan Kemampuan Komunikasi MatematisSiswa Sekolah Dasar. SEMIRATA FMIPA, (hal. 225-238).

Sugiyono. (2016). Metode penelitian kuantitatif, kualitatif, dan $R \& D$. Bandung: Alfabeta.

Trilling, B., \& Fadel, C. (2009). 21 st CENTURY SKILLS: Learning for Life in Our Times. San Francisco: Jossey-Bas.

Zulkardi, Z., Putri, R. I. I., \& Wijaya, A. (2020). Two Decades of Realistic Mathematics Education in Indonesia. https://doi.org/10.1007/978-3-030-20223-1_5 